\title{
Electronic Spectra of Chevreul's Salts
}

\author{
Luciana A. da Silva ${ }^{a}$, Jailson B. de Andrade ${ }^{*, a}$ and Henrique E. Toma ${ }^{b}$ \\ ${ }^{a}$ Instituto de Química, Universidade Federal da Bahia, Campus de Ondina, 40170-290 Salvador - BA, Brazil \\ ${ }^{b}$ Instituto de Química, Universidade de São Paulo, Cidade Universitária, 05508-900 São Paulo - SP, Brazil
}

A série isomórfica de sulfitos duplos com fórmula empírica $\mathrm{Cu}_{2} \mathrm{SO}_{3} \cdot \mathrm{MSO}_{3} \cdot 2 \mathrm{H}_{2} \mathrm{O}$ (onde $\mathrm{M}$ é $\mathrm{Cu}, \mathrm{Fe}, \mathrm{Mn}$ ou $\mathrm{Cd}$ ) é preparada pela substituição do $\mathrm{Cu}(\mathrm{II})$ no sal de Chevreul, $\mathrm{Cu}_{2} \mathrm{SO}_{3} \cdot \mathrm{CuSO}_{3} \cdot 2 \mathrm{H}_{2} \mathrm{O}$, por íons de metais de transição, tais como $\mathrm{Fe}(\mathrm{II}), \mathrm{Mn}(\mathrm{II})$ e $\mathrm{Cd}(\mathrm{II})$. Como consequiência, as espécies isomórficas apresentam colorações distintas. Cálculos de modelagem molecular foram empregados neste trabalho para o centro dimérico $\left[\mathrm{Cu}_{2}^{\mathrm{I}}\left(\underline{\mathrm{SO}}_{3}\right)_{2}\left(\mathrm{~S}_{3}\right)_{2}\right]^{6-}$. O espectro eletrônico do sal de Chevreul consiste de uma banda de transferência de carga em $425 \mathrm{~nm}$ associada ao cromóforo $\left[\mathrm{Cu}_{2}^{\mathrm{I}}\left(\underline{\mathrm{SO}}_{3}\right)_{2}\left(\mathrm{SO}_{3}\right)_{2}\right]^{6-}$ e duas transições de campo ligante a 785 e $1000 \mathrm{~nm}$ envolvendo distorção de Jahn-Teller dos níveis do $\mathrm{Cu}$ (II). Além disso, uma banda adicional de transferência de intervalência é observada em $500 \mathrm{~nm}$, sendo responsável pela sua coloração vermelha característica. A substituição do íon $\mathrm{Cu}(\mathrm{II})$ pelos íons $\mathrm{Fe}(\mathrm{II}), \mathrm{Mn}$ (II) e Cd(II) não elimina a banda de absorção em $425 \mathrm{~nm}$, associada à transição de transferência de carga centrada nos sítios $\mathrm{Cu}(\mathrm{I})$, porém a banda original em $500 \mathrm{~nm}$ desaparece, em concordância com a atribuição de transição intervalência.

The isomorphic series of double sulfites with empirical formula $\mathrm{Cu}_{2} \mathrm{SO}_{3} \cdot \mathrm{MSO}_{3} \cdot 2 \mathrm{H}_{2} \mathrm{O}$ (where $\mathrm{M}$ is $\mathrm{Cu}, \mathrm{Fe}, \mathrm{Mn}$, or $\mathrm{Cd}$ ) have been prepared from the $\mathrm{Cu}$ (II) replacement by transition metal ions such as $\mathrm{Mn}$ (II), $\mathrm{Fe}$ (II) and $\mathrm{Cd}(\mathrm{II})$ ions in Chevreul's salt, $\mathrm{Cu}_{2} \mathrm{SO}_{3} \cdot \mathrm{CuSO}_{3} \cdot 2 \mathrm{H}_{2} \mathrm{O}$. As a consequence, the isomorphic species present distinct colors. Molecular modeling calculations were carried out for the dimeric $\left[\mathrm{Cu}_{2}^{\mathrm{I}}\left(\mathrm{SO}_{3}\right)_{2}\left(\mathrm{SO}_{3}\right)_{2}\right]^{6-}$ center. The electronic spectra of the Chevreul's salt consist of a charge-transfer band around $425 \mathrm{~nm}$ associated with the $\left[\mathrm{Cu}_{2}^{\mathrm{I}}\left(\underline{\mathrm{SO}}_{3}\right)_{2}\left(\mathrm{~S}_{3}\right)_{2}\right]^{6-}$ chromophore and two ligand field transitions at 785 and $1000 \mathrm{~nm}$ involving the Jahn-Teller splitting of the $\mathrm{Cu}$ (II) levels. An additional intervalence-transfer band, responsible for its characteristic red color, can be found at 500 $\mathrm{nm}$. The replacement of the $\mathrm{Cu}$ (II) ions for $\mathrm{Fe}(\mathrm{II}), \mathrm{Mn}$ (II) and $\mathrm{Cd}(\mathrm{II})$ does not eliminate the absorption band at $425 \mathrm{~nm}$, supporting its assignment as a charge-transfer transition centered on the $\mathrm{Cu}(\mathrm{I})$ sites; while the original band at $500 \mathrm{~nm}$ disappears, in agreement with its intervalence transfer nature.

Keywords: electronic spectra, Chevreul's salt, isomorphic salts

\section{Introduction}

The first known mixed valence sulfite complex, $\mathrm{Cu}_{2}^{\mathrm{I}} \mathrm{SO}_{3} \cdot \mathrm{Cu}^{\mathrm{II}} \mathrm{SO}_{3} \cdot 2 \mathrm{H}_{2} \mathrm{O}$, was prepared by $\mathrm{M}$. Chevreul, ${ }^{1}$ in 1812. Its crystalline structure was described in terms of coordination polyhedra by Kierkegaard and Nyberg, ${ }^{2}$ consisting of $\left[\mathrm{SO}_{3}\right]$ trigonal pyramids, $\left[\mathrm{Cu}^{\mathrm{I}} \mathrm{O}_{3} \mathrm{~S}\right]$ tetrahedra and $\left[\mathrm{Cu}^{\mathrm{II}} \mathrm{O}_{4}\left(\mathrm{H}_{2} \mathrm{O}\right)_{2}\right]$ octahedra linked together, giving a three-dimensional network.

Chevreul's salt derivatives have been prepared from the $\mathrm{Cu}$ (II) replacement by transition metal ions such as $\mathrm{Mn}$ (II), $\mathrm{Fe}$ (II) and $\mathrm{Cd}$ (II) ions.-5 In such cases, the X-ray diffraction data were similar to those of Chevreul's salt, with minor

* e-mail: jailsong@ufba.br changes in "d" spacings, ${ }^{3-5}$ forming an isomorphic series, i.e., $\mathrm{Cu}_{2} \mathrm{SO}_{3} \cdot \mathrm{CuSO}_{3} \cdot 2 \mathrm{H}_{2} \mathrm{O}, \mathrm{Cu}_{2} \mathrm{SO}_{3} \cdot \mathrm{MnSO}_{3} \cdot 2 \mathrm{H}_{2} \mathrm{O}$, $\mathrm{Cu}_{2} \mathrm{SO}_{3} \cdot \mathrm{FeSO}_{3} \cdot 2 \mathrm{H}_{2} \mathrm{O}$ and $\mathrm{Cu}_{2} \mathrm{SO}_{3} \cdot \mathrm{CdSO}_{3} \cdot 2 \mathrm{H}_{2} \mathrm{O}$. As a consequence, a gradual substitution of the $\mathrm{Cu}$ (II) ions by the transition metal ions is also possible, giving rise to a variety of mixed compositions.

Interestingly, the isomorphic species present distinct colors. ${ }^{4}$ The intense red color of the Chevreul's salt changes to yellowish-brown, after the substitution of $\mathrm{Cu}$ (II) by $\mathrm{Fe}(\mathrm{II})$. If the substitution is carried out with $\mathrm{Mn}$ (II) instead of $\mathrm{Fe}(\mathrm{II})$, a gradual transition to yellow color is observed. On the other hand, if $\mathrm{Cu}(\mathrm{II})$ is replaced by $\mathrm{Cd}(\mathrm{II})$, a faint yellow color is obtained.

Although the interest for this kind of compounds dates from the beginning of the $19^{\text {th }}$ century, only recently the 
spectroscopic properties of the Chevreul's salt have been investigated by Inoue et al. ${ }^{6}$ based on EPR measurements and diffuse reflectance absorption spectra. Up to the present time, there is a complete lack of information about the electronic interactions between the constituents of Chevreul's salt derivatives, especially concerning the types of electronic transitions responsible for their different colors. For this reason, this subject is focused in this paper, with emphasis on the theoretical evaluation of the chargetransfer bands in the Chevreul's salt.

\section{Experimental}

\section{Materials}

All chemicals used in the synthesis of the double sulfites were of analytical reagent grade.

Copper, and mixtures of copper and manganese, copper and iron or copper and cadmium sulfate solutions (see compositions in Table 1) were saturated with sulfur dioxide gas at room temperature to give solutions with $\mathrm{pH}$ of approximately 1 . These solutions were heated to $78{ }^{\circ} \mathrm{C}$. The $\mathrm{pH}$ of the solutions was raised to $3.0-3.5$ by dropwise addition of a $20 \%$ sodium carbonate solution, under magnetic stirring. The precipitation of the complex sulfites starts at about $\mathrm{pH}$ 3.0. The crystalline materials were immediately collected on a filter, washed with deionized water and rinsed with ethanol, followed by air drying. A more detailed account on their syntheses can be found elsewere. ${ }^{4,5}$

Table 1. Composition of the starting solutions in the mixed valence sulfite preparations

\begin{tabular}{lccccc}
\hline Double sulfites & \multicolumn{3}{c}{$\mathrm{MSO}_{4} \cdot \mathrm{nH}_{2} \mathrm{O}^{\mathrm{a}}(\mathrm{g})$} & \multirow{2}{*}{$\begin{array}{c}\text { Solution } \\
\text { volume }(\mathrm{mL})\end{array}$} \\
\cline { 2 - 5 } & $\mathrm{Cu}$ & $\mathrm{Fe}$ & $\mathrm{Mn}$ & $\mathrm{Cd}$ & 50 \\
\hline $\mathrm{Cu}_{2} \mathrm{SO}_{3} \cdot \mathrm{CuSO}_{3} \cdot 2 \mathrm{H}_{2} \mathrm{O}$ & 2.0 & - & - & - & 50 \\
$\mathrm{Cu}_{2} \mathrm{SO}_{3} \cdot \mathrm{FeSO}_{3} \cdot 2 \mathrm{H}_{2} \mathrm{O}$ & 1.0 & 12.2 & - & - & 50 \\
$\mathrm{Cu}_{2} \mathrm{SO}_{3} \cdot \mathrm{MnSO}_{3} \cdot 2 \mathrm{H}_{2} \mathrm{O}$ & 1.0 & - & 6.2 & - & 50 \\
$\mathrm{Cu}_{2} \mathrm{SO}_{3} \cdot \mathrm{CdSO}_{3} \cdot 2 \mathrm{H}_{2} \mathrm{O}$ & 1.0 & - & - & 10.2 & 50 \\
\hline
\end{tabular}

${ }^{\mathrm{a}} \mathrm{Cu}(\mathrm{n}=5) ; \mathrm{Fe}(\mathrm{n}=7) ; \mathrm{Mn}(\mathrm{n}=1) ; \mathrm{Cd}(\mathrm{n}=8 / 3)$

\section{Measurements}

The electronic spectra were recorded on a Guided Wave spectrophotometer, model 260, equipped with a Wand bundle probe for in situ reflectance measurements. Total copper, manganese, iron, and cadmium contents were determined using an ICP/AES ARL, model 3410 instrument.

\section{Theoretical Calculations}

Molecular modeling calculations were carried out for the dimeric $\left[\mathrm{Cu}_{2}^{\mathrm{I}}\left(\underline{\mathrm{SO}}_{3}\right)_{2}\left(\mathrm{SO}_{3}\right)_{2}\right]^{6-}$ center attached to two $\left[\mathrm{Cu}^{\mathrm{II}}\left(\mathrm{H}_{2} \mathrm{O}\right)_{2}\left(\mathrm{~S}_{3}\right)_{2}\right]^{2-}$ fragments, starting from the crystallographic bond lengths, ${ }^{2}$ in order to simulate the $\left\{\mathrm{Cu}_{2}{ }_{2}\left(\underline{\mathrm{SO}}_{3}\right)_{2}\left[\mathrm{Cu}^{\mathrm{II}}\left(\mathrm{H}_{2} \mathrm{O}\right)_{2}\left(\mathrm{~S}_{3}\right)_{2}\right]_{2}\right\}^{6-}$ repetitive group (Figure 1) in the tridimensional structure of the Chevrel's salt ${ }^{2}$ $\left(\underline{S O}_{3}{ }^{2-}=\mathrm{S}\right.$ bound sulfite, $\mathrm{SO}_{3}{ }^{2-}=\mathrm{O}$ bound sulfite $)$. Geometry optimization was carried out using the $\mathrm{MM}^{+}$method within the HyperChem 6.0 program (Hypercube Inc. Gainesville, USA), and a gradient of $1 \times 10^{-6} \mathrm{kcal}(1 \mathrm{cal}=4.1840 \mathrm{~J})$ as a convergence criterion in a conjugate gradient method. Spectral simulations were carried out in separate for the $\left[\mathrm{Cu}_{2}^{\mathrm{I}}\left(\mathrm{SO}_{3}\right)_{2}\left(\mathrm{SO}_{3}\right)_{2}{ }^{16-}\right.$ center, but keeping the same previously optimized geometry for the $\left\{\mathrm{Cu}_{2}{ }_{2}\left(\underline{\mathrm{SO}}_{3}\right)_{2}\left[\mathrm{Cu}^{\mathrm{II}}\left(\mathrm{H}_{2} \mathrm{O}\right)_{2}\right.\right.$ $\left.\left.\left(\mathrm{SO}_{3}\right)_{2}\right]_{2}\right\}^{6-}$ group (Figure 1). SCF molecular orbitals were obtained at the RHF level for the closed-shell $\mathrm{Cu}(\mathrm{I})$ groundstate species, using the ZINDO/S method, ${ }^{7-10}$ and the default parameters, for single CI excitations in an active space involving 20 frontier molecular orbitals (10 highest occupied and 10 lowest unoccupied MOs).

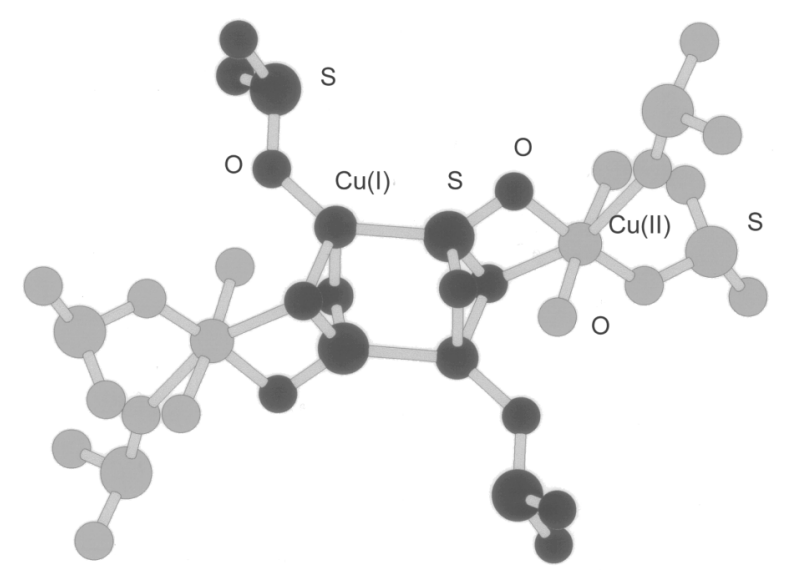

Figure 1. ZINDO/1 optimized molecular structure for the $\left\{\mathrm{Cu}_{2}^{\mathrm{I}}\left(\underline{\mathrm{S}}_{3}\right)_{2}\left[\mathrm{Cu}^{\mathrm{II}}\left(\mathrm{H}_{2} \mathrm{O}\right)_{2}\left(\mathrm{~S}_{3}\right)_{2}\right]_{2}\right\}^{6-}$ characteristic group in the Chevreul's salt, showing the $\left[\mathrm{Cu}_{2}^{\mathrm{I}}\left(\mathrm{S}_{3}\right)_{2}\left(\mathrm{~S}_{3}\right)_{2}\right]^{6-}$ unity in the center (dark) and the $\left[\mathrm{Cu}^{\mathrm{II}}\left(\mathrm{H}_{2} \mathrm{O}\right)_{2}\left(\mathrm{SO}_{3}\right)_{2}\right]^{2-}$ fragments (light).

\section{Results and Discussion}

The diffuse reflectance electronic spectrum of the Chevreul's salt reported by Inoue et al. ${ }^{6}$ in the $400-800 \mathrm{~nm}$ range, consists of two broad bands at 785 and $425 \mathrm{~nm}$. The first one has been ascribed to a d-d transition of the octahedral $\mathrm{Cu}$ (II) ions. ${ }^{6}$ The second band (at $425 \mathrm{~nm}$ ) has been tentatively assigned to an intervalence transition between the tetrahedral $\mathrm{Cu}(\mathrm{I})$ sites and the octahedral $\mathrm{Cu}$ (II) ones. This transition is responsible by the intense dark red color of the Chevreul's salt. 
In this work, the electronic spectrum of the Chevreul's salt has been extended to the near-infrared region, as illustrated in Figure 2. The spectra of the corresponding derivatives with $\mathrm{Fe}(\mathrm{II}), \mathrm{Mn}(\mathrm{II})$ and $\mathrm{Cd}(\mathrm{II})$ ions are also shown in Figure 2, for comparison purposes.

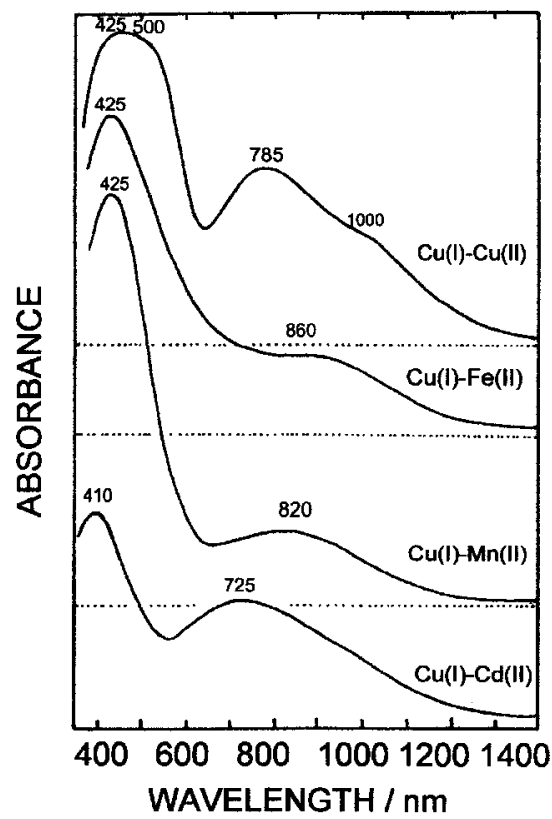

Figure 2. Diffuse reflectance spectra of the mixed valence $\mathrm{Cu}(\mathrm{I})$ $\mathrm{Cu}(\mathrm{II})$ and related $\mathrm{Cu}(\mathrm{I})-\mathrm{M}(\mathrm{II})$ Chevreul's salts, $\mathrm{Cu}_{2} \mathrm{SO}_{3} \cdot \mathrm{MSO}_{3} \cdot 2 \mathrm{H}_{2} \mathrm{O}$ $(\mathrm{M}=\mathrm{Cu}, \mathrm{Fe}, \mathrm{Mn}$, and $\mathrm{Cd})$

As can be seen in Figure 2, all the Chevreul's salt derivatives exhibit an absorption band around $425 \mathrm{~nm}$ and a less intense band in the visible region. This feature has also been recently reproduced from photoacoustic measurements. ${ }^{11}$ However, the absorption profile is markedly distinct for the Chevreul's salt, in which case the comparison with the series clearly reveals the composite nature of the absorption band in the $400-500 \mathrm{~nm}$ range. A new component can be observed at $500 \mathrm{~nm}$, and another one at $1000 \mathrm{~nm}$, in the near-infrared region not accessed by the previous work. ${ }^{6}$

The high energy band at $425 \mathrm{~nm}$ seems to be a common feature of the Chevreul's salt derivatives (see Figure 2) and accordingly, it would be better ascribed to a transition in the $\mathrm{Cu}(\mathrm{I})$-sulfite chromophore, rather than to an intervalence transfer transition. In the last case, the electronic transition would be strongly dependent on the nature of the $\mathrm{M}(\mathrm{II})$ ion. For this reason, semi-empirical theoretical calculations were carried out for the $\mathrm{Cu}(\mathrm{I})$ sulfite chromophore, in order to elucidate the characteristic electronic transitions associated with this group.

Initially, molecular modeling calculations were carried out for the dimeric $\left[\mathrm{Cu}_{2}^{\mathrm{I}}\left(\underline{\mathrm{SO}}_{3}\right)_{2}\left(\mathrm{SO}_{3}\right)_{2}\right]^{6-}$ center attached to two $\left[\mathrm{Cu}^{\mathrm{II}}\left(\mathrm{H}_{2} \mathrm{O}\right)_{2}\left(\mathrm{SO}_{3}\right)_{2}\right]^{2-}$ fragments, reproducing very closely the $\left\{\mathrm{Cu}_{2}^{\mathrm{I}}\left(\underline{\mathrm{SO}}_{3}\right)_{2}\left[\mathrm{Cu}^{\mathrm{II}}\left(\mathrm{H}_{2} \mathrm{O}\right)_{2}\left(\mathrm{~S}_{3}\right)_{2}\right]_{2}\right\}^{6-}$ characteristic group in the tridimensional structure of the Chevrel's salt. ${ }^{2}$ After the geometry optimization using the ZINDO/1 program, the two $\left[\mathrm{Cu}^{\mathrm{II}}\left(\mathrm{H}_{2} \mathrm{O}\right)_{2}\left(\mathrm{~S}_{3}\right)_{2}\right]^{2-}$ fragments were removed, leaving the $\left[\mathrm{Cu}_{2}^{\mathrm{I}}\left(\underline{\mathrm{SO}}_{3}\right)_{2}\left(\mathrm{~S}_{3}\right)_{2}\right]^{6-}$ center. In this way one can simulate the electronic properties of the $\left[\mathrm{Cu}_{2}^{\mathrm{I}}\left(\mathrm{SO}_{3}\right)_{2}\left(\mathrm{SO}_{3}\right)_{2}\right]^{6-}$ moiety, in separate, but keeping the same original structural arrangement found in Chevreul's salt. This particular chromophore is rather unusual, since it contains a dimeric, tetrahedral $\mathrm{Cu}(\mathrm{I})$ complex attached to sulfur bound, bidentate oxygen bound and monodentate oxygen bound sulfite ions, as illustrated in Figure 1.

ZINDO/S calculations for the $\left[\mathrm{Cu}_{2}^{\mathrm{I}}\left(\underline{\mathrm{SO}}_{3}\right)_{2}\left(\mathrm{SO}_{3}\right)_{2}\right]^{6-}$ center led to the HOMOs and LUMOs involved in the electronic transitions. As shown in Table 2, the three highest occupied molecular orbitals (HOMO levels number 60, 61 and 62) exhibit predominantly $\mathrm{Cu}(\mathrm{I})$ character, but incorporate a substantial contribution from the S-bound sulfite ion. The lowest unoccupied molecular orbital (LUMO 63) has a strong S-bound sulfite ion character $(83 \%)$, containing only a small contribution from the $\mathrm{Cu}(\mathrm{I})$ ion. The next level (LUMO 64) has also predominantly S-bound sulfite ion character $(63 \%)$, while the succeeding level (LUMO $65)$ involves a nearly equivalent mixture of the $\mathrm{Cu}(\mathrm{I})$ and S-bound sulfite ions.

Table 2. HOMO and LUMO composition for the $\mathrm{Cu}_{2}^{\mathrm{I}}\left(\mathrm{SO}_{3}\right)_{2}\left(\mathrm{~S}_{3}\right)_{2}$ moiety in the Chevreul's salts

\begin{tabular}{|c|c|c|}
\hline Type & $\begin{array}{c}\text { MO } \\
\text { Number }\end{array}$ & Composition $^{\mathrm{a}}$ \\
\hline HOMO & 60 & $0.625\left(\mathrm{Cu}^{\mathrm{I}}\right)+0.256\left(\underline{\mathrm{SO}}_{3}{ }^{2-}\right)+0.119\left(\mathrm{~S}_{\mathrm{O}^{2}}{ }^{2-}\right)$ \\
\hline HOMO & 61 & $0.586\left(\mathrm{Cu}^{\mathrm{I}}\right)+0.387\left(\underline{\mathrm{S}}_{3}{ }^{2-}\right)+0.027\left(\mathrm{~S}_{\mathrm{O}^{2}}{ }^{2-}\right)$ \\
\hline HOMO & 62 & $0.544\left(\mathrm{Cu}^{\mathrm{I}}\right)+0.429\left(\underline{\mathrm{S}}_{3}{ }^{2-}\right)+0.027\left(\mathrm{~S}_{\mathrm{O}^{2}}{ }^{2-}\right)$ \\
\hline LUMO & 63 & $0.135\left(\mathrm{Cu}^{\mathrm{I}}\right)+0.833\left(\underline{\mathrm{S}}_{3}{ }^{2-}\right)+0.012\left(\mathrm{~S}_{3}{ }^{2-}\right)$ \\
\hline LUMO & 64 & $0.320(\mathrm{Cu})+0.635\left(\underline{\mathrm{S}}_{3}{ }^{2-}\right)+0.045\left(\mathrm{~S}_{3}{ }^{2-}\right)$ \\
\hline LUMO & 65 & $0.547\left(\mathrm{Cu}^{\mathrm{I}}\right)+0.363\left(\underline{\mathrm{S}}_{3}{ }^{2-}\right)+0.090\left(\mathrm{~S}_{\mathbf{O}^{2}}{ }^{2-}\right)$ \\
\hline
\end{tabular}

a) $\left(\underline{\mathrm{SO}}_{3}^{2-}\right)=\mathrm{S}$ bound; $\left(\mathrm{S}_{\mathrm{O}^{2-}}{ }^{2-}\right)=\mathrm{O}$ bound

According to the ZINDO/S calculations, the lowest, moderately intense, spin-allowed electronic transitions occurs at 620 (oscillator strength $\mathrm{f}=0.033$ ) and $577 \mathrm{~nm}(\mathrm{f}$ $=0.078$ ), involving the excitation from HOMO 62 to LUMO 64, and from a combination of the HOMO 61 and 62 levels, to a combined level from LUMO 63 and 65, respectively. The next theoretically allowed transition occurs at $401 \mathrm{~nm}(\mathrm{f}=0.098)$, corresponding to the excitation from HOMO 60 to LUMO 63. Therefore the $\left[\mathrm{Cu}_{2}^{\mathrm{I}}\left(\underline{\mathrm{SO}}_{3}\right)_{2}\left(\mathrm{SO}_{3}\right)_{2}\right]^{6-}$ chromophore is expected to exhibit three absorption bands in the visible region, ascribed to 
molecular orbital transitions displaying substantial $\mathrm{Cu}^{\mathrm{I}}-$ sulfite charge-transfer character, as deduced from the HOMO and LUMO compositions.

The octahedral $\mathrm{Cu}$ (II) sites exhibit the metal ion bound to six oxygen donor ligands, and the visible band around 785 $\mathrm{nm}$ has been associated with the characteristic ligand field transition in the copper(II) ions..$^{12}$ Actually, the metal ion is bound to two water molecules $(\mathrm{d}=1.92 \AA)^{2}$ and to two pairs of non-equivalent, oxygen bound sulfite ions, at $\mathrm{d}=2.03$ and $2.46 \AA$ A. These bonding distances characterize a substantial distortion, as expected from the Jahn-Teller effect associated with the $\mathrm{d}^{9}$ ions. ${ }^{13}$ One of the consequences of the Jahn-Teller effect is the splitting of the ligand field bands in the copper(II) ions. Although this aspect has not been previously reported ${ }^{6}$ for the Chevreul's salt, the observed bands a 785 and 1000 $\mathrm{nm}$ are in good agreement the ligand field theory, reflecting the Jahn-Teller distortion in the copper(II) sites. The expected, weak charge-transfer bands in the $\left[\mathrm{Cu}_{2}^{\mathrm{I}}\left(\underline{\mathrm{S}}_{3}\right)_{2}\left(\mathrm{~S}_{3}\right)_{2}\right]^{6}$ moiety at 620 and $577 \mathrm{~nm}$ are probably superimposed to the ligands field bands in the visible.

Theoretically, neither the tetrahedral $\left[\mathrm{Cu}{ }_{2}^{\mathrm{I}}\left(\underline{\mathrm{SO}}_{3}\right)_{2}\left(\mathrm{~S}_{3}\right)_{2}\right]^{6-}$ nor the octahedral $\left[\mathrm{Cu}^{\mathrm{II}}\left(\mathrm{H}_{2} \mathrm{O}\right)_{2}\left(\mathrm{~S}_{\underline{3}}\right)_{4}\right]^{6-}$ sites are expected to exhibit electronic bands around $500 \mathrm{~nm}$. Therefore, the observed absorption at $500 \mathrm{~nm}$ in the Chevreul's salt spectrum can only be ascribed to an intervalence transfer transition from the tetrahedral $\mathrm{Cu}(\mathrm{I})$ ions to the empty $3 \mathrm{~d}_{\mathrm{x}-\mathrm{y}}^{2{ }^{2}}$ level of $\mathrm{e}_{\mathrm{g}}$ symmetry of the $\mathrm{Cu}$ (II) ions. In this case, the intervalence transfer energy can be expressed in terms of the following equation: ${ }^{12}$

$$
\mathrm{E}_{\mathrm{IT}}=30,000\left[\mathrm{X}\left(\mathrm{Cu}^{\mathrm{I}}\right)-\mathrm{X}\left(\mathrm{Cu}^{\mathrm{II}}\right)\right]+10 \mathrm{Dq}
$$

where $\mathrm{X}\left(\mathrm{Cu}^{\mathrm{I}}\right)$ and $\mathrm{X}\left(\mathrm{Cu}^{\mathrm{II}}\right)$ are the optical electronegativities of the $\mathrm{Cu}(\mathrm{I})$ and $\mathrm{Cu}(\mathrm{II})$ sites and $10 \mathrm{Dq}$ represents the ligand field splitting in a octahedral $\mathrm{Cu}(\mathrm{II})$ ion. From the ligand field transition, $10 \mathrm{Dq}$ is approximately $12,700 \mathrm{~cm}^{-1}$ Considering that $\mathrm{E}_{\mathrm{IT}}=20,000 \mathrm{~cm}^{-1}$, and that the optical electronegativity of the octahedral $\mathrm{Cu}$ (II) ions is $2.2,{ }^{14}$ the optical electronegativity of the tetrahedral $\mathrm{Cu}(\mathrm{I})$ sites in the Chevreul's salt can be calculated as 2.44.

Iron(II), and manganese(II)) ions exhibit $3 d^{6}$ and $3 d^{5}$ electronic configurations, respectively. In principle, these electronic configurations can also allow intervalence transitions, since the cations have empty $3 \mathrm{~d}$ orbitals. However, both ions are not particularly good electron acceptors, and as far we know, intervalence-transfer transitions generating iron(I) or manganese(I) excited species are quite unusual in the literature.

The Mn(II) derivative exhibits an absorption bands at $820 \mathrm{~nm}$, while the metal ion, in separate, do not display absorption bands in this particular region. The same argument can be applied for the $\mathrm{Cd}^{\mathrm{II}}$ case, which display an absorption band at $725 \mathrm{~nm}$. In the last case, it should be noticed that, from the optical electronegativity, ${ }^{14} \mathrm{X}\left(\mathrm{Cd}^{\mathrm{II}}\right)$ $=1.35$, the intervalence band in the Chevrel's salt derivative is expected around $300 \mathrm{~nm}$, i.e., in the $\mathrm{UV}$ region. Therefore, by ruling out the ligand field and intervalence transfer transitions, the observed bands for the $\mathrm{Mn}$ (II) and $\mathrm{Cd}(\mathrm{II})$ derivatives at 820 and $725 \mathrm{~nm}$ can only be ascribed to the expected low energy transitions in the $\left[\mathrm{Cu}_{2}^{\mathrm{I}}\left(\underline{\mathrm{SO}}_{3}\right)_{2}\left(\mathrm{~S}_{3}\right)_{2}\right]^{6-}$ chromophore, under the influence of the specific interactions with the $\mathrm{M}(\mathrm{II})$ ions.

In the case of the $\mathrm{Fe}$ (II) derivative, the absorption band at $860 \mathrm{~nm}$ coincides with the expected ligand field transition for high spin octahetral iron(II) complexes. ${ }^{12}$ The overall absorption profile in this case, as compared with the $\mathrm{Mn}(\mathrm{II})$ derivative, is rather broad (see Figure 1) and suggests the existence of additional bands around 600 $\mathrm{nm}$, associated low energy transitions in the $\left[\mathrm{Cu}_{2}^{\mathrm{I}}\left(\underline{\mathrm{SO}}_{3}\right)_{2}\left(\mathrm{~S}_{3}\right)_{2}\right]^{6-}$ chromophore.

\section{Conclusions}

The electronic spectrum of the Chevreul's salt consists of a charge-transfer band around $425 \mathrm{~nm}$ associated with the $\left[\mathrm{Cu}_{2}^{\mathrm{I}}\left(\underline{\mathrm{SO}}_{3}\right)_{2}\left(\mathrm{~S}_{3}\right)_{2}\right]^{6-}$ chromophore, and two ligand field transitions at 785and $1000 \mathrm{~nm}$ involving the Jahn-Teller splitting of the $\mathrm{Cu}$ (II) levels. An additional intervalencetransfer band, responsible for its red color, can be found at $500 \mathrm{~nm}$. The replacement of the $\mathrm{Cu}$ (II) ions for Fe(II), $\mathrm{Mn}$ (II) and $\mathrm{Cd}(\mathrm{II})$ does not eliminate the absorption band at 425 $\mathrm{nm}$, supporting its assignment as a charge-transfer transition centered on the $\mathrm{Cu}(\mathrm{I})$ sites. The less intense band at $860 \mathrm{~nm}$ for the $\mathrm{Fe}$ (II) derivative is consistent with a Laporte forbidden ligand field transition, while the bands at 820 and 725 in the $\mathrm{Mn}(\mathrm{II})$ and $\mathrm{Cd}(\mathrm{II})$ cases were tentatively assigned to charge-transfer transitions in the $\left[\mathrm{Cu}_{2}{ }_{2}\left(\underline{S O}_{3}\right)_{2}\left(\mathrm{SO}_{3}\right)_{2}\right]^{6-}$ chromophore, respectively, considering the lack of characteristic electronic transitions for these ions, in this region.

\section{References}

1. Chevreul, M. E.; Ann. Chim. 1812, 83, 187.

2. Kierkegaard, P.; Nyberg, B.; Acta Chem. Scand. 1965, 19, 2189.

3. Sghyar, M.; Durand, J.; Miguel, A. H.; Cot, L.; Rev. Chim. Miner. 1984, 21, 710.

4. Silva, L. A.; Correia, S. J.; Martins, C. R.; de Andrade, J. B.; Quím. Nova, 1998, 21, 151.

5. Silva, L. A.; Matos J. R.; de Andrade, J. B.; Thermochim. Acta 2000, 360, 17. 
6. Inoue, M.; Grijalva, H.; Inoue, M. B.; Fernando, Q.; Inorg. Chim. Acta 1999, 295, 125.

7. Zerner, M. C.; Loew, G. H.; Kirchner, R. F.; Mueller-Westerhoff, U. T.; J. Am. Chem. Soc. 1980, 102, 589.

8. Bacon, A. D.; Zerner, M. C.; Theoret. Chim. Acta 1979, 53, 21.

9. Ridley, J. E.; Zerner, M. C.; Theoret. Chim. Acta 1976, 42, 223.

10. Ridley, J. E.; Zerner, M. C.; Theoret. Chim. Acta 1973, 32, 111

11. Silva, L. A.; de Andrade J. B.; Moysés Araújo, C.; Nakamura, O.; Ferreira da Silva, A.; Massunaga, M. S. O.; Vargas, H.; Phys. Chem. Chem. Phys. 2001, 3, 4800.
12. Lever, A. B. P.; Inorganic Electronic Spectroscopy, Elsevier: Amsterdam, 1984

13. Huheey, J. E.; Keiter, E. A.; Keiter, R.; Inorganic Chemistry: Principles of Struture and Reactivity, 4th ed., Harper Collins College Publishers: New York, 1993.

14. Duffy, J. A.; Bonding, Energy Levels and Bands in Inorganic Solids, John Wiley: New York, 1990.

Received: November 11, 2001

Published on the web: August 7, 2002

FAPESP helped in meeting the publication costs of this article. 